\title{
Pathotype, Resistance Classification, and Seed-Coating Control of Heterodera avenae and $H$. filipjevi in the North China Plain
}

\author{
Jiangkuan Cui, ${ }^{1, \dagger}$ Yongqing Jiao, ${ }^{1}$ Bo Zhou, ${ }^{1}$ Haohao Ren, ${ }^{1}$ Hao Li, ${ }^{1}$ Shiming Liu, ${ }^{2}$ Shijun Jiang, ${ }^{1}$ Haoguang Meng, ${ }^{1}$ Minmin Li, ${ }^{3}$ \\ Abdelfattah Amer Dababat, ${ }^{4}$ and Deliang Peng ${ }^{2, \dagger}$ \\ ${ }^{1}$ College of Plant Protection, National Key Laboratory of Wheat and Maize Crop, Henan Agricultural University, Zhengzhou \\ 450002, China \\ ${ }^{2}$ State Key Laboratory for Biology of Plant Diseases and Insect Pests, Institute of Plant Protection, Chinese Academy of Agri- \\ cultural Sciences, Beijing 100193, China \\ ${ }^{3}$ Plant Protection Central Station of Shandong Province, Jinan Shandong 250100, China \\ ${ }^{4}$ CIMMYT (International Maize and Wheat Improvement Centre), Ankara 06511, Turkey
}

\begin{abstract}
Heterodera avenae and $H$. filipjevi are cereal cyst nematodes (CCNs) that infect cereals in 16 provinces of China. $\mathrm{CCN}$ populations from Xuchang, Tangyin, Qihe, and Juye were tested using 23 barley, oat, and wheat entries of the International Test Assortment for Defining Cereal Cyst Nematode Pathotypes. H. avenae populations from Tangyin, Qihe, and Juye were classified as pathotype Ha91, and H. filipjevi from Xuchang was classified as a new pathotype similar to pathotype West. Among 42 other winter wheat cultivars, 29 and 30 were differentially

resistant to $H$. filipjevi. Coating wheat seed with abamectin + isopycnic imidacloprid or methylene (bis) thiocyanate + thiamethoxam reduced the number of $H$. avenae and $H$. filipjevi cysts by 46 to $56 \%$, increased wheat yield by 9 to $27 \%$, and improved net income by 660 to 2,640 Chinese Yuan ha ${ }^{-1}$, respectively. Resistant wheat cultivars are scarce in China, and seed coating is considered the most suitable method for controlling CCNs in the North China Plain, where crop rotation cannot be practiced.
\end{abstract} susceptible, 13 and 12 were differentially resistant to $H$. avenae and $H$. filipjevi, respectively. Three entries were resistant to both species, and three other entries were resistant to $H$. avenae and moderately
Keywords: cereal cyst nematode, pathotype West, pathotype Ha91, seed coating, wheat resistance
As the staple food for $35 \%$ of the global population, wheat (Triticum aestivum L.) is one of the most important crops worldwide (Singh et al. 2011). The most globally recognized and economically important wheat-damaging nematodes are the cereal cyst nematodes (CCNs) Heterodera avenae, $H$. filipjevi, and H. latipons (Nicol et al. 2011). In Australia, grain loss caused by $H$. avenae was estimated to be 20 to $50 \%$ for barley and wheat, with an annual economic loss of $\$ 58$ million (Murray and Brennan 2009). In Turkey, H. filipjevi is economically important, causing an average yield loss of $42 \%$ in rain-fed winter wheat (Nicol et al. 2006). In the Pacific Northwest region of the United States, the annual impact on wheat production by the CCN was estimated to be approximately 21,000 tons, valued at $\$ 3.4$ million (Smiley 2009). In China, an area of more than 4 million ha in major wheat-producing regions is infested by the CCNs, resulting in 10 to $40 \%$ reductions in wheat grain yield (Cui et al. 2015). Where the density of CCNs is greater than 10 eggs $g$ soil ${ }^{-1}$, yield losses can range from 16 to 55\% (Hou et al. 2012). H. avenae (Wollenweber 1924) was first identified in Hubei Province of China in 1989 (Chen et al. 1992) and has subsequently been reported in Henan, Hebei, Beijing, Inner Mongolia, Qinghai, and Anhui Provinces. H. avenae

${ }^{\dagger}$ Corresponding authors: J. Cui; jiangk.cui@henau.edu.cn; and D. Peng; dlpeng@ippcaas.cn

Funding: This research was supported by the National Natural Science Foundation of China (31801717), the Key Scientific Research Projects Plan of Henan Higher Education Institutions (19A210017), the Open Research Fund of the State Key Laboratory for Biology of Plant Diseases and Insect Pests (SKLOF201910), and the Special Fund for Young Talents in Henan Agricultural University (30500663)

The author(s) declare no conflict of interest.

Accepted for publication 1 June 2020.

(C) 2020 The American Phytopathological Society has been detected in a total of 16 wheat-producing provinces in China (Cui et al. 2015). H. filipjevi (Madzhidov 1981) Stelter 1984 was first reported in Henan Province in 2010 (Peng et al. 2010) and subsequently detected in Anhui Province, the Xinjiang Uygur Autonomous Region, and Shandong Province (Peng et al. 2016, 2018; Zhen et al. 2018). The infestation of wheat by CCNs is increasing in China, resulting in losses of 1.9 billion Chinese Yuan (CNY) year $^{-1}$ (Peng et al. 2009).

The relative ability of a nematode to damage a particular plant is defined as "pathogenicity" (Nicol et al. 2011). The first pathotype of $H$. avenae was defined by Andersen (1959), after which Andersen and Andersen (1982) reviewed the pathotype variations in H. avenae and established the "International Cereal Test Assortment for Defining Cereal Cyst Nematode Pathotypes". The four cultivars Ortolan (Rha1+), KVL 191 (Rha2+), Siri (Rha2+), and Morocco (Rha3+) could distinguish $\mathrm{CCN}$ pathotypes; group 1 is avirulent to cultivars with the resistance gene $\mathrm{Hal}$, group 2 is virulent to those cultivars with the resistance gene $\mathrm{Hal}$ but not to cultivars with the resistance gene $\mathrm{Ha}$, and group 3 is virulent to cultivars with both the resistance genes $\mathrm{Hal}$ and $\mathrm{Ha} 2$ but not to cultivars with the resistance gene $\mathrm{Ha} 3$ (Andersen and Andersen 1982; Cook and Rivoal 1998). Andersen and Andersen (1982) reported that the "H. avenae" populations that were initially designated as pathotypes $\mathrm{Ha} 23$ and $\mathrm{Ha} 33$ were actually pathotypes of the closely related species H. filipjevi. Ireholm (1994) distinguished $H$. filipjevi pathotypes $\mathrm{G}$ (West) and $\mathrm{G}$ (East), known as the $H$. avenae Gotland race in Sweden. To date, 15 H. avenae pathotypes have been described and named worldwide (Cui et al. 2015). At least three pathotypes of $H$. filipjevi can be differentiated using the International Cereal Test Assortment (Holgado et al. 2004; Subbotin et al. 2010; Toktay et al. 2013). However, there are no reports of $H$. filipjevi pathotypes being distinguished in China.

Multiple studies and control measures have been performed to overcome the CCN problem globally. The use of resistant and tolerant wheat varieties has been the most effective, economically beneficial, and environmentally friendly option for controlling these nematodes (Nicol et al. 2011; Smiley et al. 2012, 2017). After 
suitable resistance sources from barley and wild wheat relatives were identified and confirmed, the resistance genes were transferred to different cultivars (Ogbonnaya et al. 2001). However, Smiley et al. (2017) indicated that the effect of designated Cre genes depends on both the CCN species and pathotypes. Currently, applications of chemical nematicides are among the primary means for controlling plant-parasitic nematodes. Fosthiazate is effective for reducing and suppressing Globodera pallida hatching (Woods et al. 1999). The application of abamectin (Aba) + carbendazim + thiram as a seed coating treatment effectively decreased the number of soybean cyst nematodes with a control efficiency of $48 \%$ (Chen et al. 2008). Soil applications of $\mathrm{Aba}$ at a rate of $45 \mathrm{~kg} \mathrm{ha}^{-1}$ in greenhouse and field trials significantly decreased the number of $\mathrm{CCN}$ white females by 66 to $77 \%$ and 47 to $65 \%$, respectively, and increased the wheat grain yield by $19 \%$ (Zhang et al. 2017). Coating seed with methylene (bis) thiocyanate (MT) and MT + thiamethoxam (MTT) reduced the number of $H$. avenae cysts by 53 and $56 \%$ and increased wheat yield by 38 and 19\%, respectively (Hao et al. 2014). Cui et al. (2017c) demonstrated that the application of seed treatments with $1.0 \% \mathrm{MT}+10 \%$ MTT (flowable concentration for seed coating [FSC]) and 3\% fipronil $+15 \%$ chlorpyrifos (FSC) effectively decreased the number of cysts, inhibited the reproduction of Heterodera spp., and increased the wheat yield under field conditions.

The objectives of this study were to (i) characterize the pathotypes of three populations of $H$. avenae and one population of $H$. filipjevi collected from a major wheat-producing region, (namely, the North China Plain), (ii) screen international and Chinese winter wheat sources that might carry resistance genes that could be transferred to locally adapted cultivars via introgression and subsequently deployed to control CCNs, and (iii) test and evaluate the pathogenicity of different pathotypes of CCNs in China.

\section{Materials and Methods}

Nematode collection. CCNs were collected from the soil of severely infested wheat fields in Xuchang $\left(34^{\circ} 02^{\prime} 019^{\prime \prime} \mathrm{N}, 113^{\circ} 44^{\prime}\right.$ $023^{\prime \prime}$ E) and Tangyin ( $\left.35^{\circ} 53^{\prime} 057^{\prime \prime} \mathrm{N}, 114^{\circ} 26^{\prime} 011^{\prime \prime} \mathrm{E}\right)$ in Henan Province and in Qihe ( $\left.36^{\circ} 57^{\prime} 065^{\prime \prime} \mathrm{N}, 116^{\circ} 57^{\prime} 023^{\prime \prime} \mathrm{E}\right)$ and Juye ( $35^{\circ} 17^{\prime} 012^{\prime \prime}$ $\mathrm{N}, 115^{\circ} 55^{\prime} 028^{\prime \prime}$ E) in Shandong Province, China, at the end of the wheat growing season. These locations, which are separated by 250 to $350 \mathrm{~km}$, represent four counties with heavy infestations of $H$. avenae and $H$. filipjevi that have caused significant damage to wheat. Cysts were extracted from the soil via Cobb's sieving gravity method (Persmark et al. 1992). Using molecular methods previously described by Qi et al. (2012) and Peng et al. (2013), the nematodes collected in Xuchang were identified as $H$. filipjevi and those collected from Tangyin, Qihe, and Juye were identified as $H$. avenae. The cysts were incubated at $4{ }^{\circ} \mathrm{C}$ for 60 days and then at $16^{\circ} \mathrm{C}$ to stimulate the hatching of preparasitic second-stage juveniles (J2s).

Experimental design. Pathotype tests. Four $\mathrm{CCN}$ pathotype tests were conducted to distinguish the $H$. avenae populations from Tangyin, Qihe, and Juye and $H$. filipjevi populations from Xuchang. Seed of standard hosts, including 13 barley species, 6 oat species, and 7 wheat species (Table 1), were germinated in Petri dishes and then transplanted into polyvinyl chloride (PVC) tubes $(3 \mathrm{~cm}$ in diameter and $25 \mathrm{~cm}$ in length) that contained $150 \mathrm{~cm}^{3}$ of a sterile soil mixture (loamy soil/compost/sand = 3:2:5). Approximately $300 \mathrm{~J} 2 \mathrm{~s}$ were placed into each tube immediately after seed planting, and two additional batches of $250 \mathrm{~J} 2 \mathrm{~s}$ were added at 3-day intervals to obtain a final inoculum density of approximately 800 juveniles per tube (Cui et al. 2015). The susceptible (S) wheat cultivars Wenmai 19 and Aikang 58 were used as local controls. Each cultivar underwent five replicates four times. Plants were grown in a glasshouse for 1 week at 14 and $18^{\circ} \mathrm{C}, 2$ weeks at 16 and $20^{\circ} \mathrm{C}, 5$ weeks at 18 and $25^{\circ} \mathrm{C}$, and 2 weeks at 22 and $30^{\circ} \mathrm{C}$, under $8 \mathrm{~h}$ of darkness and $16 \mathrm{~h}$ of light and

Table 1. Reactions of international standard hosts to populations of cereal cyst nematodes from four locations in the North China Plain ${ }^{z}$

\begin{tabular}{|c|c|c|c|c|c|c|c|c|}
\hline \multirow[b]{2}{*}{ Entry (resistance gene) } & \multicolumn{2}{|c|}{ Xuchang } & \multicolumn{2}{|c|}{ Tangyin } & \multicolumn{2}{|c|}{ Qihe } & \multicolumn{2}{|c|}{ Juye } \\
\hline & Mean & PR & Mean & PR & Mean & PR & Mean & PR \\
\hline \multicolumn{9}{|l|}{ Barley } \\
\hline Varde & $26.7 \pm 4.9$ & + & $33.9 \pm 4.7$ & + & $27.8 \pm 2.8$ & + & $38.3 \pm 3.7$ & + \\
\hline Emir $(R h a E)$ & 0 & - & $2.3 \pm 0.7$ & $(-)$ & $\mathrm{Nt}$ & $\mathrm{Nt}$ & $\mathrm{Nt}$ & $\mathrm{Nt}$ \\
\hline Ortolan (Rhal+) & $1.3 \pm 1.5$ & - & $0.3 \pm 0.4$ & - & 0 & - & 0 & - \\
\hline KVL 191 (Rha2+) & $4.5 \pm 1.8$ & $(+)$ & $1.5 \pm 0.7$ & $(-)$ & $4.0 \pm 1.3$ & $(+)$ & $5.1 \pm 1.8$ & $(+)$ \\
\hline Siri $(R h a 2+)$ & $1.5 \pm 0.9$ & - & 0 & - & 0 & - & 0 & - \\
\hline Morocco $(R h a 3+)$ & $2.7 \pm 1.6$ & $(-)$ & $0.7 \pm 0.6$ & - & $0.3 \pm 0.5$ & - & $0.3 \pm 0.4$ & - \\
\hline Marocaine C.I.8341 & $0.7 \pm 0.9$ & - & 0 & - & $2.9 \pm 1.8$ & $(+)$ & $4.5 \pm 1.3$ & $(+)$ \\
\hline Bajo Aragon 1-1 (Rha2) & $1.3 \pm 1.2$ & - & 0 & - & 0 & - & 0 & - \\
\hline Herta & $3.8 \pm 1.7$ & $(+)$ & $0.7 \pm 1.1$ & - & 0 & - & 0 & - \\
\hline Martin 403-2 (Rha2+) & $1.1 \pm 0.7$ & - & 0 & - & $1.2 \pm 1.1$ & - & $0.4 \pm 0.6$ & - \\
\hline Dalmatische & $13.2 \pm 3.0$ & + & $20.3 \pm 4.6$ & + & $13.1 \pm 2.6$ & + & $20.5 \pm 4.1$ & + \\
\hline La Estanzuela & 0 & - & $7.5 \pm 1.7$ & + & $6.5 \pm 2.1$ & + & $12.5 \pm 2.7$ & + \\
\hline Harlan 43 & $27.3 \pm 6.5$ & + & $4.8 \pm 1.1$ & $(+)$ & $0.9 \pm 0.6$ & - & $1.3 \pm 0.7$ & - \\
\hline \multicolumn{9}{|l|}{ Oat } \\
\hline ANSI & 0 & - & 0 & - & 0 & - & 0 & - \\
\hline Sun II & $0.4 \pm 0.6$ & - & 0 & - & 0 & - & 0 & - \\
\hline IGV.H72-646 & $29.2 \pm 9.4$ & + & $26.6 \pm 5.0$ & + & $0.1 \pm 0.3$ & - & $2.3 \pm 2.0$ & $(-)$ \\
\hline Silva (>1 gene) & $0.7 \pm 0.6$ & - & 0 & - & 0 & - & 0 & - \\
\hline I. 376 & 0 & - & 0 & - & 0 & - & 0 & - \\
\hline Pusa hybrid BS1 (Rl) & $0.7 \pm 0.6$ & - & 0 & - & 0 & - & 0 & - \\
\hline \multicolumn{9}{|l|}{ Wheat } \\
\hline Capa & $55.6 \pm 8.3$ & + & $41.6 \pm 5.9$ & + & $31.3 \pm 4.7$ & + & $34.6 \pm 5.2$ & + \\
\hline Loros×Koga $(\mathrm{Cre} 1)$ & $33.4 \pm 6.2$ & + & $27.3 \pm 4.2$ & + & $20.8 \pm 3.3$ & + & $25.2 \pm 4.1$ & + \\
\hline Iskamisch-K-2-light & $43.9 \pm 16.9$ & + & $20.1 \pm 3.9$ & + & $1.5 \pm 1.0$ & $(-)$ & $2.8 \pm 1.9$ & $(+)$ \\
\hline AUS 10894 (Crel) & $48.2 \pm 6.5$ & + & $34.3 \pm 7.8$ & + & $29.2 \pm 6.2$ & + & $31.3 \pm 5.9$ & + \\
\hline Psathias & $14.1 \pm 3.9$ & + & $11.9 \pm 2.4$ & + & $3.7 \pm 1.1$ & $(+)$ & $4.5 \pm 1.3$ & $(+)$ \\
\hline Aikang 58 & $49.0 \pm 5.8$ & + & $32.6 \pm 4.4$ & + & $31.1 \pm 8.2$ & + & $33.7 \pm 11.5$ & + \\
\hline Wenmai 19 & $61.0 \pm 8.3$ & + & $48.3 \pm 2.7$ & + & $44.6 \pm 6.9$ & + & $52.2 \pm 12.3$ & + \\
\hline
\end{tabular}

${ }^{\mathrm{z}}$ Data are presented as the means \pm standard deviation of 20 replicates. Phenotypic reactions (PR) are classified as follows: - indicates resistant $(<3 \%$ of the white females present on the local cultivar Wenmai 19$),(-)$ indicates moderately resistant (3 to $5 \%),(+)$ indicates moderately susceptible $(5$ to $10 \%),+$ indicates susceptible (>10\%), and Nt indicates not tested. 
normal culturing practices (irrigation, fertilization, and disease and insect control). Ten weeks after the last inoculation, the wheat roots and soil were washed with a gentle stream of tap water over a 250$\mu \mathrm{m}$ sieve. White female nematodes attached to the roots and soil were collected and counted under a stereoscope, and the mean numbers of white females per plant were calculated. The cultivars were categorized by resistance responses on the basis of a rating system (Smiley et al. 2011). The degree of resistance was classified as resistant (R), moderately resistant (MR), moderately susceptible (MS), and $\mathrm{S}$ if the plants contained less than 3, 3 to 5, 5 to 10 , and more than $10 \%$, respectively, of the number of white females present on the most $\mathrm{S}$ wheat cultivar (Wenmai 19).

Resistance tests. The resistance tests involved a subset of the 42 most promising wheat cultivars screened against $\mathrm{CCN}$ populations from the International Wheat and Maize Improvement Center (CIMMYT) and from the North China Plain, the major wheat-growing area in China (Table 2). The seed were germinated in Petri dishes, and five replicates of each cultivar were transplanted into PVC tubes, as previously described. Cysts from a population of $H$. avenae $\mathrm{Ha} 91$ from Daxing County in Beijing Province (Cui et al. 2015) and from the Xuchang population of $H$. filipjevi were hatched at 14 to $16^{\circ} \mathrm{C}$. Freshly hatched $\mathrm{J} 2 \mathrm{~s}$ were used to infect the roots of wheat plants, as previously described. Ten weeks after the last inoculation, the wheat roots and soil were washed, and white females were collected and counted, as described previously. The degree of resistance of the cultivars was classified as follows on the basis of the number of cysts per root system: immune (M) (0 females), R (0.1 to 5.0 females), MR (5.1 to 10.0 females), MS (10.1 to 15.0 females), S (15.1 to $25.0 \mathrm{fe}-$ males), and highly susceptible (HS) (>25.0 females) (Nicol et al. 2009).

Field trials of chemical treatments. Four seed-coating compounds were tested against CCN populations of $H$. avenae from Tangyin

Table 2. Results of the most promising wheat cultivars from China and International Maize and Wheat Improvement Centre (CIMMYT) screened against the Heterodera avenae Ha91 (Daxing population) and H. filipjevi (Xuchang population) from China

\begin{tabular}{|c|c|c|c|c|c|c|}
\hline \multirow[b]{3}{*}{ Entry (cross name) } & \multirow[b]{3}{*}{ Origin } & \multirow[b]{3}{*}{ Season } & \multicolumn{4}{|c|}{ Cereal cyst nematode $\mathbf{R R}^{\mathbf{z}}$} \\
\hline & & & \multicolumn{2}{|c|}{ H. avenae } & \multicolumn{2}{|c|}{ H. filipjevi } \\
\hline & & & Mean & $\mathbf{R R}$ & Mean & $\mathbf{R R}$ \\
\hline Aizao8-15 & Henan & Semiwinter & $0.4 \pm 0.51$ & $\mathrm{R}$ & $1.1 \pm 0.88$ & $\overline{\mathrm{R}}$ \\
\hline GA951079-3-5/Neuse & CIMMYT & Winter & $1.6 \pm 0.89$ & $\mathrm{R}$ & $9.4 \pm 2.70$ & MR \\
\hline $\begin{array}{l}\text { MV17/3/Azd/Vee"s"//Seri82/Rsh/4/Fln/ } \\
\text { Acc//Ana/3/Pew"s"/5/Rsk/CA8055// } \\
\text { Cham6 }\end{array}$ & CIMMYT & Winter & $1.8 \pm 1.09$ & $\mathrm{R}$ & $4.0 \pm 1.00$ & $\mathrm{R}$ \\
\hline Wo0608 & Anhui & Semiwinter & $2.8 \pm 0.79$ & $\mathrm{R}$ & $6.6 \pm 2.59$ & MR \\
\hline Mirzabey 2000 & CIMMYT & Winter & $3.2 \pm 1.30$ & $\mathrm{R}$ & $2.0 \pm 1.58$ & $\mathrm{R}$ \\
\hline Xinong509 & Shaanxi & Semiwinter & $3.4 \pm 1.34$ & $\mathrm{R}$ & $9.4 \pm 2.63$ & MR \\
\hline Zhong155 & Beijing & Semiwinter & $5.2 \pm 1.39$ & MR & $7.5 \pm 2.95$ & MR \\
\hline Wanke06290 & Anhui & Weak spring & $5.8 \pm 1.55$ & MR & $9.1 \pm 3.14$ & MR \\
\hline Xin25 & Henan & Semiwinter & $6.1 \pm 1.73$ & MR & $18.5 \pm 3.84$ & $\mathrm{~S}$ \\
\hline Zheng7698 & Henan & Semiwinter & $6.5 \pm 1.35$ & MR & $19.9 \pm 4.31$ & S \\
\hline Wennong14 & Shandong & Semiwinter & $6.9 \pm 1.45$ & MR & $16.7 \pm 2.11$ & S \\
\hline Pingan8 & Henan & Semiwinter & $7.4 \pm 1.58$ & MR & $18.8 \pm 4.47$ & $S$ \\
\hline Patwin & CIMMYT & Winter & $13.0 \pm 2.12$ & MS & $1.2 \pm 0.83$ & $\mathrm{R}$ \\
\hline Fengdecun1 & Henan & Semiwinter & $14.0 \pm 2.71$ & MS & $31.9 \pm 8.74$ & HS \\
\hline Pfau/Milan//Fung Mai 24 & CIMMYT & Winter & $14.2 \pm 3.11$ & MS & $7.8 \pm 3.76$ & MR \\
\hline Tosunbey & CIMMYT & Winter & $16.0 \pm 2.23$ & $\mathrm{~S}$ & $29.4 \pm 7.53$ & HS \\
\hline Zhengyu9989 & Henan & Semiwinter & $16.7 \pm 2.11$ & S & $28.8 \pm 7.22$ & HS \\
\hline Jinhe9123 & Hebei & Semiwinter & $17.8 \pm 3.15$ & S & $14.5 \pm 2.41$ & MS \\
\hline Aizao4110 & Henan & Weak spring & $20.1 \pm 3.38$ & S & $35.1 \pm 5.84$ & HS \\
\hline Clear White & CIMMYT & Winter & $21.0 \pm 4.89$ & $\mathrm{~S}$ & $23.0 \pm 5.24$ & $\mathrm{~S}$ \\
\hline P8-6 & CIMMYT & Winter & $27.0 \pm 9.35$ & HS & $6.6 \pm 2.70$ & MR \\
\hline Taishan22 & Shandong & Semiwinter & $28.8 \pm 7.22$ & HS & $21.4 \pm 4.38$ & $\mathrm{~S}$ \\
\hline Huai29 & Anhui & Semiwinter & $29.7 \pm 3.06$ & HS & $36.9 \pm 5.04$ & HS \\
\hline Taikong6 & Henan & Weak spring & $29.8 \pm 6.37$ & HS & $15.4 \pm 3.86$ & $\mathrm{~S}$ \\
\hline Zhongyu6 & Henan & Semiwinter & $30.9 \pm 3.35$ & HS & $14.9 \pm 2.60$ & MS \\
\hline Tarm (Ankara-98) & CIMMYT & Winter & $31.2 \pm 6.14$ & HS & $6.6 \pm 0.54$ & MR \\
\hline Shixin733 & Hebei & Semiwinter & $31.6 \pm 4.88$ & HS & $28.6 \pm 4.48$ & HS \\
\hline Bainong207 & Henan & Semiwinter & $32.5 \pm 7.12$ & HS & $39.9 \pm 3.21$ & HS \\
\hline Liangxing66 & Hebei & Semiwinter & $34.1 \pm 4.93$ & HS & $40.7 \pm 5.10$ & HS \\
\hline Anara & CIMMYT & Winter & $35.6 \pm 7.73$ & HS & $32.4 \pm 5.77$ & HS \\
\hline Bainong196 & Henan & Semiwinter & $36.2 \pm 5.98$ & HS & $48.5 \pm 5.58$ & HS \\
\hline Hual & Jiangsu & Semiwinter & $37.0 \pm 6.41$ & HS & $44.2 \pm 5.31$ & HS \\
\hline Ak702 & CIMMYT & Winter & $38.4 \pm 7.92$ & HS & $13.6 \pm 3.21$ & MS \\
\hline Aikang58 & Henan & Semiwinter & $39.3 \pm 5.10$ & HS & $56.0 \pm 6.65$ & HS \\
\hline Yujiao5 & Henan & Semiwinter & $41.9 \pm 7.43$ & HS & $43.9 \pm 6.51$ & HS \\
\hline Huai18 & Anhui & Semiwinter & $43.0 \pm 5.09$ & HS & $33.0 \pm 4.13$ & HS \\
\hline Zhou27 & Henan & Semiwinter & $43.5 \pm 4.30$ & HS & $38.8 \pm 5.12$ & HS \\
\hline Taishan24 & Shandong & Semiwinter & $44.1 \pm 6.01$ & HS & $28.0 \pm 3.89$ & HS \\
\hline Ji22 & Shandong & Semiwinter & $44.7 \pm 4.39$ & HS & $25.2 \pm 5.37$ & HS \\
\hline Kern (YR15; GPC; 2NS) & CIMMYT & Winter & $45.0 \pm 9.47$ & HS & $9.6 \pm 4.72$ & MR \\
\hline Zhou18 & Henan & Semiwinter & $51.2 \pm 7.98$ & HS & $30.7 \pm 4.06$ & HS \\
\hline Shannong 820 & Shandong & Semiwinter & $66.1 \pm 8.21$ & HS & $51.3 \pm 5.52$ & HS \\
\hline
\end{tabular}

${ }^{\mathrm{z}} \mathrm{RR}=$ resistance reaction; mean \pm standard error. The degree of resistance of the cultivars was classified based on the number of cysts per root system as follows: immune (M, 0 females), resistant (R, 0.1 to 5.0 females), moderately resistant (MR, 5.1 to 10.0 females), moderately susceptible (MS, 10.1 to 15.0 females), susceptible (S, 15.1 to 25.0 females), and highly susceptible (HS, $>25.0$ females). 
(pathotype Ha91) and H. filipjevi from Xuchang (new pathotype) in Henan Province during the 2017 and 2018 wheat seasons. The plots were $10 \mathrm{~m}$ long and $3.5 \mathrm{~m}$ wide (18 plant rows), and the wheat cultivar Aikang 58 was used. Three replicates were arranged as randomized complete blocks. Compound fertilizer $\left(\mathrm{N}+\mathrm{P}_{2} \mathrm{O}_{5}+\mathrm{K}_{2} \mathrm{O}\right.$, 18-18-18; Shandong Stanley Fertilizer Co., Ltd., Linyi, Shandong Province, China) was applied at a rate of $450 \mathrm{~kg} \mathrm{ha}^{-1}$, and urea was applied at $150 \mathrm{~kg} \mathrm{ha}^{-1}$ at the tillering stage (Feekes 3.0 wheat growth stage) (Large 1954). The wheat seed were coated with Aba (10\% active ingredient [a.i.], suspension concentration; Zhongda Agricultural Technology Co., Ltd., Qingdao, Shandong Province, China) and isopycnic imidacloprid (Imi; $60 \%$ a.i., FSC, Bayer Crop Science, Hangzhou City, China), MTT (1.0\% MT and 10\% thiamethoxam FSC; Gansu Agricultural University, China), fosthiazate (10\% a.i., granular; Ishihara Industries Corp., Japan), or tap water. Aba + Imi, MTT, or water were mixed with seed $\left(25 \mathrm{ml} \mathrm{kg}^{-1}\right)$ using a Huaxing 100 seed dresser (Huaxing Machinery Co., Ltd., Guangzhou, Guangdong Province, China). Granular fosthiazate $\left(30 \mathrm{~kg} \mathrm{ha}^{-1}\right)$ was applied to the fields, which were plowed with a 3 wg-11 garden tiller (Keshida Agricultural Machinery Group Co., Ltd., Weifang, Shandong Province, China) 1 day before planting. The seed were planted using a 2BXF-9 drill (Nonghaha Machinery Group Co., Ltd., Shijiazhuang, Hebei Province, China) equipped with a disk coulter and nine openers spaced $18 \mathrm{~cm}$ apart. The seed were sown at a rate of $150 \mathrm{~kg} \mathrm{ha}^{-1}$ into moist soil at a depth of 3 to $5 \mathrm{~cm}$ when the seed-zone temperature was 15 to $17^{\circ} \mathrm{C}$. Normal cultural practices such as irrigation; fertilization; and weed, disease, and insect control were performed by field workers.

The initial population $\left(P_{i}\right)$ densities of nematodes in the experimental area were determined by collecting five samples in a zigzag pattern from each of the 12 plots. Similarly, the final population $\left(P_{f}\right)$ densities of mature brown cysts in the field were determined after wheat harvest. Each sample comprised a composite of 15 soil cores $2.5 \mathrm{~cm}$ in diameter and $35 \mathrm{~cm}$ deep. The collected soil cores were thoroughly mixed, and three $100-\mathrm{cm}^{3}$ subsamples were removed for counting (Cui et al. 2017c). The cysts were extracted from the soil by wet sieving and sucrose flotation centrifugation (Zheng et al. 1995), then counted using a stereomicroscope. The agronomic characteristics of the treated wheat plants (spike number per square meter, thousand-seed weight, and grain yield per square meter) were compared with those of the untreated control plants after three random $1-\mathrm{m}^{2}$ areas of each plot were harvested with a KTY-100 seed sheller (Xinchang Machinery Group Co., Ltd., Weihui, Henan Province, China).

Statistical analysis. The wheat growth indices, grain yield, number of white female cysts in the greenhouse pot trials, and number of mature brown cysts in the field trials were subjected to statistical analyses. Analysis of variance was performed individually for each experiment. Significant differences $(P \leq 0.05)$ among treatments were determined in conjunction with the least significant difference test via SPSS 12.0 software (SPSS Inc.).

The reproductive factor $(\mathrm{RF})$ and reduction in population over the control (ROC) metrics were calculated to reflect the protective efficacy of the chemicals against CCNs (Jagdale and Grewal 2002). The following equations were used in the statistical analyses:

$$
R F=P_{f} / P_{i}
$$

ROC $=($ cyst number of the control - cyst number of treatment $) \times$ $100 \%$ /cyst number of the control

$$
\begin{gathered}
\text { Yield increase }(\%)=(\text { yield of treatment }- \text { yield of the control }) \times \\
100 \% / \text { yield of the control }
\end{gathered}
$$

\section{Results}

Pathotype tests. The number of white females on the roots of each plant was counted at 70 days after inoculation with $800 \mathrm{H}$. filipjevi from a population from Xuchang and $H$. avenae populations from Tangyin, Qihe, and Juye. The four repeat tests showed similar results, and the responses of each cultivar and the mean number of white females per plant are shown in Table 1 . The local wheat cultivar Wenmai 19 produced the largest number of white females among all of the populations.

For the $H$. filipjevi population, no white females were observed on the barley cultivars Emir (RhaE) and La Estanzuela. Ortolan (Rhal+), Siri (Rha2+), Marocaine C.I.8341, Bajo Aragon1-1 (Rha2), and Martin 403-2 (Rha2+) were also classified as R, with a mean number of white females less than $1.8(<3 \%$ of white females present on cultivar Wenmai 19). However, KVL 191 (Rha2+) was MS and Morocco (Rha3+) was MR to the tested H. filipjevi population, with mean white female numbers of 4.5 and 2.7, respectively. Varde and Harlan 43 were the most $S$ cultivars in barley group, with mean white female numbers of 26.7 and 27.3, respectively. All of the oat cultivars were strongly R, with the exception of IGV.H72-646, which was S, with a mean of 29.2 white females. All of the wheat cultivars were $\mathrm{S}$ to the $H$. filipjevi population, and Capa was the most $\mathrm{S}$ wheat cultivar, with a mean of 55.6 white females. In summary, the results observed for the $H$. filipjevi population from Xuchang were inconsistent with the reaction of pathotype East, particularly for the cultivars carrying resistance genes; namely, Ortolan (Rhal+), Siri (Rha2+), Martin 403-2 (Rha2+), and Morocco (Rha3+) that can distinguish CCN pathotypes (Table 3 ). Although the responses of Ortolan (Rhal+), KVL 191 (Rha2+), Siri (Rha2+), Bajo Aragon 1-1 (Rha2), and Morocco (Rha3+) were identical to those obtained with pathotype West when challenged with the $H$. filipjevi population from Xuchang, the responses obtained for barley with Martin 4032 (Rha2+) and Herta, oat with Sun II (minor genes), and wheat with Psathias were inconsistent with those obtained for pathotype West (Table 3). Furthermore, the reaction data regarding Marocaine

Table 3. Resistance reactions of 23 standard reference cereals to Heterodera

\begin{tabular}{|c|c|c|c|c|c|}
\hline \multirow[b]{2}{*}{ Cereal cultivar } & \multirow{2}{*}{$\frac{\text { Present study }}{\text { XC }}$} & \multicolumn{2}{|c|}{$\begin{array}{c}\text { Ireholm } \\
\text { West }\end{array}$} & \multicolumn{2}{|c|}{$\begin{array}{c}\text { Ireholm } \\
\text { East }\end{array}$} \\
\hline & & NH & Mol & Et & Ha \\
\hline \multicolumn{6}{|l|}{ Barley } \\
\hline Varde & $\mathrm{S}$ & $\mathrm{S}$ & $\mathrm{S}$ & $\mathrm{S}$ & $\mathrm{S}$ \\
\hline Ortolan $(R h a l+)$ & $\mathrm{R}$ & $\mathrm{R}$ & $\mathrm{R}$ & S & S \\
\hline KVL 191 (Rha2+) & S & (R) & $(\mathrm{S})$ & $*$ & S \\
\hline Siri $(R h a 2+)$ & $\mathrm{R}$ & $\mathrm{R}$ & $\mathrm{R}$ & $\mathrm{S}$ & $\mathrm{S}$ \\
\hline Morocco (Rha3+) & (R) & $\mathrm{R}$ & $(\mathrm{S})$ & S & S \\
\hline Marocaine C.I.8341 & $\mathrm{R}$ & $*$ & $*$ & $*$ & $*$ \\
\hline Bajo Aragon 1-1 (Rha2) & $\mathrm{R}$ & $\mathrm{R}$ & $\mathrm{R}$ & $\mathrm{R}$ & $\mathrm{R}$ \\
\hline Herta & (S) & $\mathrm{R}$ & $\mathrm{R}$ & * & $*$ \\
\hline Martin 403-2 (Rha2+) & $\mathrm{R}$ & $\mathrm{S}$ & $\mathrm{S}$ & $\mathrm{S}$ & $\mathrm{S}$ \\
\hline Dalmatische & $\mathrm{S}$ & * & * & * & * \\
\hline La Estanzuela & $\mathrm{R}$ & $\mathrm{R}$ & $\mathrm{R}$ & $\mathrm{R}$ & $\mathrm{R}$ \\
\hline Harlan 43 & S & (R) & (S) & (S) & (S) \\
\hline \multicolumn{6}{|l|}{ Oat } \\
\hline ANSI & $\mathrm{R}$ & * & $*$ & $*$ & $*$ \\
\hline Sun II (minor genes) & $\mathrm{R}$ & S & S & (S) & S \\
\hline IGV.H72-646 & $\mathrm{S}$ & $*$ & $*$ & $*$ & $*$ \\
\hline Silva (>1 gene) & $\mathrm{R}$ & $*$ & $*$ & $*$ & $*$ \\
\hline I.376 (1-3 dominant genes) & $\mathrm{R}$ & $\mathrm{R}$ & $\mathrm{R}$ & $\mathrm{R}$ & (S) \\
\hline Pusa Hybrid BS1 (Rl) & $\mathrm{R}$ & $*$ & $*$ & $*$ & $*$ \\
\hline \multicolumn{6}{|l|}{ Wheat } \\
\hline Capa & S & S & S & S & S \\
\hline Loros×Koga $(\mathrm{Cre} 1)$ & $\mathrm{S}$ & $\mathrm{S}$ & $\mathrm{S}$ & $\mathrm{S}$ & $\mathrm{S}$ \\
\hline Iskamish-K-2-light & $\mathrm{S}$ & * & * & $*$ & $*$ \\
\hline AUS 10894 (Crel) & S & $\mathrm{S}$ & S & S & $\mathrm{S}$ \\
\hline Psathias & S & $\mathrm{R}$ & $\mathrm{R}$ & $\mathrm{R}$ & (S) \\
\hline
\end{tabular}
filipjevi populations from China in this study and as reported by Ireholm $(1994)^{2}$

${ }^{\mathrm{z}}$ Populations in the present study ( $\mathrm{XC}=$ Xuchang County in Henan Province, China) and in a previous report by Ireholm (1994) $(\mathrm{NH}=$ Norra Harene population in Sweden, pathotype West; Mol = Molltorp population in Sweden, pathotype West; Et = Etelhem population in Sweden, pathotype East; and $\mathrm{Ha}=$ Havor population in Sweden, pathotype East). $\mathrm{R}=$ resistant, $\mathrm{S}=$ susceptible, $(\mathrm{S})$ or $(\mathrm{R})=$ intermediate reaction, and $*=$ not tested. 
C.I.8341, Dalmatische, ANSI, IGV.H72-646, Silva, Pusa Hybrid BS1 (RI), and Iskamish-K-2-light for pathotype West were lacking (Ireholm 1994). Our results indicated that the $H$. filipjevi population from Xuchang was a new pathotype.

The $H$. avenae populations from Tangyin, Qihe, and Juye exhibited similar resistance responses. Ortolan (Rhal+), Siri (Rha2+), Martin 403-2 (Rha2+), Bajo Aragon1-1 (Rha2), Morocco (Rha3+), and Herta showed high resistance to the three populations. Marocaine C.I.8341 was R to the Tangyin population and MS to the Qihe and Juye populations. Harlan 43 was MR to the Tangyin population and $\mathrm{R}$ to the Qihe and Juye populations. The most $\mathrm{S}$ barley cultivar was Varde, followed by Dalmatische and La Estanzuela, with 33.9, 27.8, and 38.3 mean white females, respectively. IGV.H72-646 was $\mathrm{S}$ to the Tangyin population, and all of the other tested oat cultivars were nearly R. Most of the tested wheat cultivars were $\mathrm{S}$ to the three $H$. avenae populations, except Iskamish K-2-light, which was MR to the Qihe population. In conclusion, the resistance responses of six cultivars carrying resistance genes distinguished CCN pathotypes: the responses of Ortolan (Rhal+), KVL 191 (Rha2+), Siri (Rha2+), Bajo Aragon 1-1 (Rha2), Martin 403R2 $(R h a 2+)$, and Morocco (Rha3+) were completely consistent with pathotype Ha91 (Table 4). The responses of the other cultivars, with the exception of Marocaine C.I.834, were all consistent with pathotype Ha91 (Table 4). Our data supported the conclusion that the H. avenae populations from Tangyin, Qihe, and Juye were pathotype Ha91.

Resistance tests. Resistance screening of the 42 target cultivars of winter wheat from China and CIMMYT (Table 2) revealed that 22

Table 4. Resistance reactions of 23 cultivars in the International Test Assortment for Defining Cereal Cyst Nematode Pathotypes to the populations of Heterodera avenae in the North China Plain, compared with $H$. avenae Ha91 described by Cui et al. $(2015)^{\mathrm{z}}$

\begin{tabular}{|c|c|c|c|c|c|}
\hline \multirow[b]{2}{*}{ Cereal cultivar } & \multicolumn{3}{|c|}{ Present study } & \multicolumn{2}{|c|}{$\begin{array}{c}\text { Cui et al. } \\
\text { (2015) }\end{array}$} \\
\hline & TY & QH & JY & HY & DX \\
\hline \multicolumn{6}{|l|}{ Barley } \\
\hline Varde & $\mathrm{S}$ & $\mathrm{S}$ & $\mathrm{S}$ & S & $\mathrm{S}$ \\
\hline Ortolan $(R h a l+)$ & $\mathrm{R}$ & $\mathrm{R}$ & $\mathrm{R}$ & $\mathrm{R}$ & $\mathrm{R}$ \\
\hline KVL 191 (Rha2+) & $(\mathrm{S})$ & $(\mathrm{S})$ & $(\mathrm{S})$ & $\mathrm{S}$ & $(\mathrm{S})$ \\
\hline Siri $(R h a 2+)$ & $\mathrm{R}$ & $\mathrm{R}$ & (S) & $\mathrm{R}$ & $\mathrm{R}$ \\
\hline Morocco (Rha3+) & $\mathrm{R}$ & $\mathrm{R}$ & $\mathrm{R}$ & $\mathrm{R}$ & $\mathrm{R}$ \\
\hline Marocaine C.I. 8341 & $\mathrm{R}$ & $(\mathrm{S})$ & $(\mathrm{S})$ & (S) & $\mathrm{S}$ \\
\hline Bajo Aragon 1-1 (Rha2) & $\mathrm{R}$ & $\mathrm{R}$ & $\mathrm{R}$ & $\mathrm{R}$ & $\mathrm{R}$ \\
\hline Herta & $\mathrm{R}$ & $\mathrm{R}$ & $\mathrm{R}$ & $(\mathrm{S})$ & $\mathrm{R}$ \\
\hline Martin 403R2 (Rha2+) & $\mathrm{R}$ & $\mathrm{R}$ & $\mathrm{R}$ & $\mathrm{R}$ & $\mathrm{R}$ \\
\hline Dalmatische & $S$ & $\mathrm{~S}$ & S & S & $\mathrm{S}$ \\
\hline La Estanzuela & $\mathrm{S}$ & $\mathrm{S}$ & $\mathrm{S}$ & S & $\mathrm{S}$ \\
\hline Harlan 43 & (R) & $\mathrm{R}$ & $\mathrm{R}$ & $\mathrm{S}$ & $\mathrm{R}$ \\
\hline \multicolumn{6}{|l|}{ Oat } \\
\hline ANSI & $\mathrm{R}$ & $\mathrm{R}$ & $\mathrm{R}$ & (R) & $\mathrm{R}$ \\
\hline Sun II & $\mathrm{R}$ & $\mathrm{R}$ & $\mathrm{R}$ & (R) & $\mathrm{R}$ \\
\hline IGV.H72R646 & $\mathrm{S}$ & $\mathrm{R}$ & $(\mathrm{S})$ & $\mathrm{R}$ & $\mathrm{S}$ \\
\hline Silva (>1 gene) & $\mathrm{R}$ & $\mathrm{R}$ & $\mathrm{R}$ & $\mathrm{R}$ & $\mathrm{R}$ \\
\hline I.376 A. sterilis & $\mathrm{R}$ & $\mathrm{R}$ & $\mathrm{R}$ & $\mathrm{R}$ & $\mathrm{R}$ \\
\hline Pusa Hybrid BS1 (Rl) & $\mathrm{R}$ & $\mathrm{R}$ & $\mathrm{R}$ & $\mathrm{R}$ & $\mathrm{R}$ \\
\hline \multicolumn{6}{|l|}{ Wheat } \\
\hline Capa & $\mathrm{S}$ & S & $\mathrm{S}$ & $\mathrm{S}$ & $\mathrm{S}$ \\
\hline Loros×Koga $(\mathrm{Crel})$ & S & $\mathrm{S}$ & $\mathrm{S}$ & $\mathrm{S}$ & $\mathrm{S}$ \\
\hline Iskamish-K-2-light & S & (R) & (R) & $(\mathrm{S})$ & $\mathrm{R}$ \\
\hline AUS 10894 (Crel) & S & $\mathrm{S}$ & $\mathrm{S}$ & $\mathrm{S}$ & $\mathrm{S}$ \\
\hline Psathias & $\mathrm{S}$ & $(\mathrm{S})$ & (S) & (S) & (S) \\
\hline
\end{tabular}

${ }^{\mathrm{z}}$ Populations in the present study (TY = Tangyin County in Henan Province, $\mathrm{QH}=$ Qihe County in Shandong Province, and JY = Juye County in Shandong Province) and in a previous report by Cui et al. (2015) (HY = Huangyuan County in Qinghai Province and DX = Daxing County in Beijing Province). Pathotype groups are those of Andersen and Andersen (1982), which were based on virulence to the $\mathrm{Hal}, \mathrm{Ha}$, and $\mathrm{Ha} 3$ resistance genes. $\mathrm{R}=$ resistant, $\mathrm{S}=$ susceptible, $(\mathrm{S})$ or $(\mathrm{R})=$ intermediate reaction, and $*$ not tested. were HS, 5 were S, 3 were MS, 6 were MR, and 6 were R to the Daxing population of $H$. avenae pathotype Ha91 and 19 were HS, 7 were S, 3 were MS, 9 were MR, and 4 were R to the Xuchang population classified as the new $H$. filipjevi pathotype. GA951079-3-5/Neuse, Wo0608, and Xinong509 were R to $H$. avenae and MR to $H$. filipjevi. Patwin was R to $H$. filipjevi but MS to $H$. avenae, and Zhong 155 and Wanke 06290 were MR to the $H$. avenae and $H$. filipjevi populations. Xin25, Zheng7698, Wennong 14, and Pingan 8 were MR to the $H$. avenae population but $\mathrm{S}$ to the $H$. filipjevi population. Pfau/Milan// Fung Mai 24, P8-6, Tarm (Ankara-98), and Kern (YR15; GPC; 2NS) were differentially $\mathrm{S}$ to the $H$. avenae population but MR to the $H$. filipjevi population. The other tested wheat cultivars were $\mathrm{S}$ to the two CCN populations. The local $\mathrm{S}$ wheat cultivar Aikang 58 and the tolerant wheat cultivar Taikong 6 were HS and S to the $H$. avenae and $H$. filipjevi populations, respectively (Table 2 ).

All of the main wheat cultivars in China such as Aikang 58, Zhou18, Ji22, Shixin 733, Liangxing 66, Huai29 and Hual were S or HS to both $H$. filipjevi and $H$. avenae pathotype Ha91 (Table 2). Some cultivars from CIMMYT displayed good resistance to $H$. avenae pathotype $\mathrm{Ha} 91$ but not to the $H$. filipjevi population from Xuchang. Only 3 of the 42 most promising wheat cultivars tested (Aizao8-15, Mirzabey2000, and MV17/3/Azd/Vee"s"//Seri82/Rsh/ 4/Fln/Acc//Ana/3/Pew"s"/5/Rsk/CA8055//Cham6) were R to both $H$. filipjevi and $H$. avenae pathotype $\mathrm{Ha} 91$ (Table 2 ). The resistance reactions for the $H$. avenae pathotype Ha91 populations from Daxing and Tangyin were similar to each other but were significantly different from that to the H. filipjevi population from Xuchang (Table 5). The virulence of the $H$. filipjevi and $H$. avenae populations differed strongly according to the pathogenic spectrum results. Out of 16 wheat lines or cultivars, 4, 9, and 3 were classified as R, MR, and MS, respectively, to the $H$. filipjevi population from Xuchang; 6, 2, 2,1 , and 5 were classified as R, MR, MS, S, and HS, respectively, to the $H$. avenae population from Daxing; and 5, 2, 2, 4, and 3 were classified as R, MR, MS, S, and HS, respectively, to the $H$. avenae population from Tangyin (Table 5). The results showed that not only the species and the pathotypes but also different populations from the same pathotypes could impact the effectiveness of the specified $\mathrm{R}$ cultivars.

Table 5. Resistance reactions of the most promising lines or cultivars of winter wheat screened against Heterodera filipjevi populations from China in this and previous studies

\begin{tabular}{|c|c|c|c|}
\hline \multirow[b]{3}{*}{ Entry } & \multicolumn{3}{|c|}{ Reaction $^{\mathrm{y}}$} \\
\hline & \multicolumn{2}{|c|}{ H. avenae } & \multirow{2}{*}{$\frac{\text { H. filipjev }}{\text { Xuchang }}$} \\
\hline & Daxing & Tangyin & \\
\hline Aizao8-15 & $\mathrm{R}$ & $\mathrm{R}$ & $\mathrm{R}$ \\
\hline $\begin{array}{l}\text { MV17/3/Azd/Vee"s"//Seri82/ } \\
\text { Rsh/4/Fln/Acc//Ana/3/Pew"s"/ } \\
\text { 5/Rsk/CA8055//Cham6z }\end{array}$ & $\mathrm{R}$ & $\mathrm{R}$ & $\mathrm{R}$ \\
\hline Mirzabey $2000^{z}$ & $\mathrm{R}$ & $\mathrm{R}$ & $\mathrm{R}$ \\
\hline Patwin $^{\mathrm{z}}$ & MS & MS & $\mathrm{R}$ \\
\hline Xinong509 & $\mathrm{R}$ & $\mathrm{R}$ & MR \\
\hline GA951079-3-5/Neuse ${ }^{\mathrm{z}}$ & $\mathrm{R}$ & $\mathrm{R}$ & MR \\
\hline Wo0608 & $\mathrm{R}$ & MR & MR \\
\hline Zhong155 & MR & MR & MR \\
\hline Wanke06290 & MR & MS & MR \\
\hline$P 8-6^{z}$ & HS & $\mathrm{S}$ & MR \\
\hline Pfau/Milan//Fung Mai 24z & MS & HS & MR \\
\hline Kern (YR15; GPC; 2NS) ${ }^{\mathrm{z}}$ & HS & HS & MR \\
\hline Tram $(\text { Ankara-98) })^{\mathrm{z}}$ & HS & HS & MR \\
\hline $\mathrm{Ak} 702^{\mathrm{z}}$ & HS & $\mathrm{S}$ & MS \\
\hline Jinhe9123 & $\mathrm{S}$ & $\mathrm{S}$ & MS \\
\hline Zhongyu6 & HS & $\mathrm{S}$ & MS \\
\hline
\end{tabular}

${ }^{\mathrm{y}} \mathrm{R}=$ resistant, $\mathrm{MR}=$ moderately resistant, $\mathrm{MS}=$ moderately susceptible, $\mathrm{S}=$ susceptible, and HS = highly susceptible.

${ }^{\mathrm{z}}$ Most-promising lines or cultivars of winter wheat screened against $\mathrm{H}$. filipjevi populations reported by Dababat et al. (2015). 
Field trials of chemical treatments. Effects of chemicals on CCN cysts. All of the chemicals tested in the 2017 and 2018 trials were effective at controlling $H$. avenae and $H$. filipjevi. For each population, the postharvest cyst densities did not differ among the chemical treatments but were significantly lower than those of controls. For $H$. avenae, the Aba + Imi combination was the most effective, with an ROC of $56 \%$ and an RF of 0.80 (Table 6). Compared with the initial density, the postharvest cyst density in the control treatment group increased by $77 \%$ for $H$. avenae and $129 \%$ for $H$. filipjevi. The RFs in the $H$. filipjevi plots treated with fosthiazate, Aba + Imi, and MTT were 1.45, 1.28, and 1.19, respectively. MTT was the most effective chemical treatment for $H$. filipjevi cyst control, with a mean ROC of $47 \%$ (Table 6 ).

Effects of chemicals on wheat yields and economic benefits. Compared with the control treatment, the fosthiazate, Aba + Imi, and MTT treatments increased tillering, thousand-kernel weight, and grain yield (Table 7). However, no differences among nematicide treatments were found for either $H$. avenae or $H$. filipjevi. The largest numerical percent increase in grain yield was obtained with the application of fosthiazate for the control of $H$. avenae (28\%) and Aba + Imi for the control of $H$. filipjevi (19\%). Significant increases in the thousand-kernel weight and grain yield were obtained from seed-coating treatment with Aba + Imi for the control of both nematode populations (Table 7).

According to the average market purchase prices for wheat in Xinxiang City in Henan Province in June 2018, the net return was calculated based on the increase in wheat yield minus the costs of the chemical products and application. For the field infested with $H$. avenae, Aba + Imi resulted in the highest additional net income, at 176 CNY $667 \mathrm{~m}^{-2}\left(=2,640 \mathrm{CNY} \mathrm{ha}^{-1}\right)$, followed by MTT, at $136 \mathrm{CNY}$
$667 \mathrm{~m}^{-2}\left(=2,040 \mathrm{CNY}^{-1}\right)$. For the field infested with $H$. filipjevi, $\mathrm{Aba}+\mathrm{Imi}$ again resulted in the greatest additional net income, at 100 CNY $667 \mathrm{~m}^{-2}\left(=1,500 \mathrm{CNY} \mathrm{ha}^{-1}\right)$, followed by MTT, at $40 \mathrm{CNY}$ $667 \mathrm{~m}^{-2}$ (= $\left.660 \mathrm{CNY} \mathrm{ha}{ }^{-1}\right)$ (Table 7). For both species, the rate of increase with fosthiazate was positive but the additional net income was negative because the market price of fosthiazate was very high in China.

Overall, the ROCs for Aba + Imi and MTT on H. avenae cysts were 56 and $54 \%$, respectively, and, under these treatments, the wheat yield increased by 27 and $20 \%$, resulting in net income valued of 176 and $136 \mathrm{CNY} 667 \mathrm{~m}^{-2}$, respectively. The ROCs for Aba + Imi and MTT on $H$. filipjevi cysts were 46 and $47 \%$, respectively, and wheat yield was increased by 19 and $9 \%$, resulting in additional net incomes of 100 and $40 \mathrm{CNY} 667 \mathrm{~m}^{-2}$, respectively.

\section{Discussion}

Identifications of novel pathotypes of $H$. avenae and $H$. filipjevi have been much performed. Peng and Cook (1996) first reported that the pathotypes of $H$. avenae populations in China might differ from those in other regions but they did not indicate the identity of those pathotypes. Zheng et al. (1997) demonstrated that the H. avenae populations in Taigu and Guzhen were distinctive new pathotypes, and Yuan et al. (2010) reported a new pathotype (Ha43) from Xushui and Xingyang, China. Cui et al. (2015) classified H. avenae from the Daxing and Huangyuan populations as the new pathotype Ha91. In the present study, all of the tested barley, oat, and wheat cultivars exhibited the same responses to the three CCN populations from Tangyin, Qihe, and Juye that were clustered into group 1 (Andersen and Andersen 1982) as those to pathotype Ha91 (Table 4); therefore, the virulence phenotype of these three

Table 6. Effects of seed treatment chemicals on the number of cysts in fields naturally infested with Heterodera avenae in Tangyin and $H$. filipjevi in Xuchang

\begin{tabular}{|c|c|c|c|c|c|}
\hline \multirow[b]{2}{*}{ Population, chemicals ${ }^{x}$} & \multirow[b]{2}{*}{ Dosage } & \multicolumn{2}{|c|}{ Number of cysts in $100 \mathrm{ml}$ of soil } & \multirow[b]{2}{*}{$\mathbf{R F}^{\mathbf{y}}$} & \multirow[b]{2}{*}{$\operatorname{ROC}(\%)^{\mathrm{z}}$} \\
\hline & & Seeding & Harvesting & & \\
\hline \multicolumn{6}{|l|}{ H. avenae } \\
\hline Fosthiazate (GR) (g/ha) & 30,000 & $8.6 \pm 2.07 \mathrm{a}$ & $7.4 \pm 2.07 \mathrm{~b}$ & 0.86 & 52.56 \\
\hline $\mathrm{Aba}(\mathrm{SC})+\operatorname{Imi}(\mathrm{FSC})(\mathrm{ml} / \mathrm{kg})$ & 10 & $8.4 \pm 1.34 \mathrm{a}$ & $6.8 \pm 1.30 \mathrm{~b}$ & 0.80 & 56.41 \\
\hline MTT (FSC) $(\mathrm{ml} / \mathrm{kg})$ & 25 & $8.0 \pm 1.58 \mathrm{a}$ & $7.2 \pm 1.78 \mathrm{~b}$ & 0.90 & 53.84 \\
\hline Tap water & $\ldots$ & $8.8 \pm 2.39 \mathrm{a}$ & $15.6 \pm 3.36 \mathrm{a}$ & 1.77 & \\
\hline \multicolumn{6}{|l|}{ H. filipjevi } \\
\hline Fosthiazate (GR) (g/ha) & 30,000 & $13.0 \pm 2.23 \mathrm{a}$ & $18.8 \pm 2.86 \mathrm{~b}$ & 1.45 & 37.75 \\
\hline $\mathrm{Aba}(\mathrm{SC})+\operatorname{Imi}(\mathrm{FSC})(\mathrm{ml} / \mathrm{kg})$ & 10 & $12.8 \pm 3.27 \mathrm{a}$ & $16.4 \pm 2.41 \mathrm{~b}$ & 1.28 & 45.69 \\
\hline MTT (FSC) $(\mathrm{ml} / \mathrm{kg})$ & 25 & $13.4 \pm 2.30 \mathrm{a}$ & $15.0 \pm 3.16 \mathrm{~b}$ & 1.19 & 47.02 \\
\hline Tap water & $\ldots$ & $13.2 \pm 3.49 \mathrm{a}$ & $30.2 \pm 5.80 \mathrm{a}$ & 2.29 & \\
\hline
\end{tabular}

${ }^{\mathrm{x}} \mathrm{Aba}=$ abamectin, $\mathrm{Imi}=$ isopycnic imidacloprid, MTT $=$ methylene $(\mathrm{bis})$ thiocyanate + thiamethoxam, $\mathrm{GR}=$ granular, $\mathrm{SC}=$ suspension concentrate, $\mathrm{FSC}=$ flowable concentrate for seed coating.

y Reproduction factor.

${ }^{\mathrm{z}}$ Reduction in population over the control.

Table 7. Effects of seed treatment chemicals on the agronomic characteristics and net income of wheat ${ }^{\mathrm{w}}$

\begin{tabular}{|c|c|c|c|c|c|}
\hline Population, treatments ${ }^{x}$ & Spike number/m² & TKW $^{\mathbf{y}}$ & Yield per $\mathbf{m}^{2}\left(\mathrm{~g} / \mathrm{m}^{2}\right)$ & Yield increase (\%) & Net income $(\mathrm{CNY})^{\mathrm{z}}$ \\
\hline \multicolumn{6}{|l|}{ H. avenae } \\
\hline Fosthiazate & $464.2 \pm 11.90 \mathrm{~b}$ & $45.9 \pm 1.06 \mathrm{~b}$ & $646.8 \pm 48.99 b$ & 28.2 & -92 \\
\hline $\mathrm{Aba}+\mathrm{Imi}$ & $472.8 \pm 10.28 b$ & $45.2 \pm 1.32 \mathrm{~b}$ & $638.6 \pm 65.39 b$ & 26.6 & 176 \\
\hline MTT & $466.0 \pm 15.38 b$ & $45.4 \pm 1.48 b$ & $606.2 \pm 21.53 b$ & 20.2 & 136 \\
\hline Tap water & $431.8 \pm 12.85 \mathrm{a}$ & $41.2 \pm 1.42 \mathrm{a}$ & $504.4 \pm 54.81 \mathrm{a}$ & $\ldots$ & $\ldots$ \\
\hline \multicolumn{6}{|l|}{ H. filipjevi } \\
\hline Fosthiazate & $442.3 \pm 19.01 \mathrm{~b}$ & $43.6 \pm 0.35 \mathrm{ab}$ & $481.0 \pm 31.19 \mathrm{ab}$ & 8.8 & -257 \\
\hline $\mathrm{Aba}+\mathrm{Imi}$ & $454.3 \pm 12.09 \mathrm{~b}$ & $50.0 \pm 2.08 \mathrm{~b}$ & $527.0 \pm 44.31 \mathrm{~b}$ & 19.2 & 100 \\
\hline MTT & $439.7 \pm 31.07 \mathrm{~b}$ & $47.3 \pm 8.15 \mathrm{ab}$ & $483.7 \pm 45.08 \mathrm{ab}$ & 9.4 & 40 \\
\hline Tap water & $403.3 \pm 12.58 \mathrm{a}$ & $37.8 \pm 6.41 \mathrm{a}$ & $442.0 \pm 34.04 \mathrm{a}$ & $\ldots$ & $\ldots$ \\
\hline
\end{tabular}

${ }^{\mathrm{w}}$ Data are shown as the means plus standard deviation. The same letters within a column indicate no significant differences at $P \leq 0.05$.

x $\mathrm{Aba}=$ abamectin, Imi $=$ isopycnic imidacloprid, and MTT $=$ methylene (bis) thiocyanate + thiamethoxam.

y Thousand-kernel weight.

${ }^{\mathrm{z}}$ Net income $=$ additional wheat yields in a $667-\mathrm{m}^{2}$ field after treatment minus the cost of the chemical treatments and application. CNY= Chinese Yuan. 
populations could be classified as pathotype Ha91 (Cui et al. 2015). Regarding $H$. filipjevi, the Gotland population was able to reproduce on barley line KVL 191, which is R to pathotypes Ha11 and Ha12 (Ireholm 1994). Martin 403-2 and KVL 191 were S to the typical pathotype G West populations from Norra Harene and Molltorp, while Herta, Siri, Emir, Ortolan, and Bajo Aragon 1-1 were highly resistant (HR) to this pathotype (Ireholm 1994). The results of the barley cultivars from Varde, Emir, Ortolan, and Morocco showed that the studied $H$. filipjevi pathotypes were similar to $H$. filipjevi pathotype West (Table 3). Moreover, all of the wheat cultivars displayed a high degree of susceptibility to the $H$. filipjevi population from Xuchang; nevertheless, AUS 10894 was MS to the Norra Harene population, and Psathias was R to the Norra Harene and Molltorp populations (Ireholm 1994). The responses of the tested cultivars to the $H$. filipjevi population from Xuchang were consistent with the results of previous reports on the $H$. filipjevi population in Norway but only five entries in the test assortment were tested by Holgado et al. (2004). Furthermore, the responses differed from the response to the $H$. filipjevi population pathotype from Huaiyang, Henan Province, because the virulence of the Huaiyang population was broader and more intense (Yuan et al. 2011a).

There have been 18 population pathotypes identified in China (Cui et al. 2015; Peng and Cook 1996; Yuan et al. 2010, 2011a; Zheng et al. 1997). The initial resistance responses of the pathotypes in these studies were classified on the basis of the number of cysts per root system: $\mathrm{R}(<10.0$ females) and $\mathrm{S}$ ( $>10.0$ females). Gradients of resistance to one plant disease are usually observed among different environments, populations, and testing methods; thus, this is not the most appropriate criterion for evaluating resistance (Smiley et al. 2011; Toumi 2017). Here, we complied with the most widely used resistance evaluation criterion: $\mathrm{R}=$ resistant $(<3 \%$ of white females present on the most susceptible control cultivar), $\mathrm{MR}=$ moderately resistant (3 to 5\%), MS = moderately susceptible (5 to $10 \%$ ), and S $=$ susceptible $(>10 \%)$ (Smiley et al. 2011). Clearly, the resistance evaluation criteria in those tests were not identical. The lack of a common and standard screening method, including a common scale for resistance, makes global comparisons of pathotype results difficult (Toumi 2017).

$\mathrm{R}$ resources are very scarce in China. Zheng et al. (1999) tested 22 main wheat cultivars from eight provinces in the North China Plain; among them, only Yangzhou 5 and Zhengzhou 831 showed resistance while the others were $\mathrm{S}$ or MS to the $H$. avenae population from Taigu in Shanxi Province (Zheng et al. 1999). No R lines were found and most of the local wheat cultivars were HS to the $H$. avenae population in Shandong Province of China (J. Liu et al. 2012; Zhao et al. 2012). In all, 40 cultivars from five provinces were tested in a greenhouse experiment, and 3 cultivars - namely, Huamai 1, Wenliang 58, and Yumai 66-18 - were R; whereas, in field trials, only Huamai 1 showed resistance to the $H$. avenae population from Peixian County in Jiangsu Province (B. Liu et al. 2012). Hou et al. (2018) obtained four spring wheat lines-MY00653, MY001302, MY001307, and MY001592-from 209 foreign spring wheat germplasm sources, which showed resistance to the $H$. avenae Ha91 population from Qinghai Province, China. According to a 3-year field and greenhouse experiment, Gao et al. (2012) found that two T. durum cultivars from Canada (Waskana and Waskowa) were HR to both $H$. filipjevi and $H$. avenae populations in Henan Province, China; nevertheless, the results also demonstrated that small numbers of $H$. filipjevi and $H$. avenae juveniles could easily penetrate Waskana and Waskowa roots. Yuan et al. (2011b) tested 75 wheat cultivars or lines from CIMMYT, and found that 1 spring and 2 winter wheat cultivars showed resistance and moderate resistance, respectively, to the $H$. filipjevi population from Xuchang in Henan Province. Similar resistance results were also obtained in previous studies (Li et al. 2013; Xing et al. 2014). Though most of the main wheat cultivars in China were $S$, we found that three cultivars or lines in the present study displayed good resistance to the $H$. avenae pathotype $\mathrm{Ha} 91$ and $H$. filipjevi population from Xuchang.

Few resistance genes against $\mathrm{CCN}$ s have been documented in hexaploid bread wheat (T. aestivum) (Cui et al. 2017a; Smiley
2014; Smiley et al. 2012). However, most of these resistance genes provide resistance to limited or specific pathotypes of CCNs (Nicol et al. 2009). Ogbonnaya et al. (2001) reported the inhibition of Ha 13 nematode reproduction in the order Cre $6>$ Cre $1>$ Cre $8 \geq$ Cre 5 . Nicol et al. (2009) reported that both $\mathrm{CreR}$ and $\mathrm{Crel}$ were effective sources of resistance against $H$. avenae populations in Henan Province, China but the Crel genes were compatible with $H$. filipjevi and $H$. avenae pathotype $\mathrm{Ha} 91$ (Cui et al. 2015, 2017a; Yuan et al. 2011b). In the present study, Wo0608, Xinong509, Zhong 155, and Wanke 06290 from China were found to be R or MR to both $H$. avenae pathotype Ha91 and $H$. filipjevi (Table 2). The genes of these cultivars provide total or partial resistance to different $\mathrm{CCN}$ pathotypes; however, the genes conferring resistance to these cultivars remain unclear. We found that some of the cultivars with effective resistance to $H$. filipjevi populations from Turkey (Dababat et al. 2015) such as Ak702 were not R to the H. filipjevi population from China (Table 5). Zheng et al. (1999) revealed that wheat cultivars $\mathrm{R}$ to the Australian $H$. avenae population were $\mathrm{S}$ to the $H$. avenae population from Taigu in Shanxi Province, China. We inferred that the main reasons for the differences in resistance were related to pathotype differences, highly variable virulence (i.e., the capability to reproduce on R plants), and highly variable reproductive capacity (Dababat et al. 2014; Rivoal et al. 2001; Toktay et al. 2013).

In China, the practices recommended for managing CCNs are currently limited and generally not profitable for farmers, and the most acceptable method is seed coating (Cui et al. 2017b; Hao et al. 2014). Fosthiazate is effective against Meloidogyne spp. and Pratylenchus spp. (Pullen and Fortnum 1999). Recently, fosthiazate was used against Heterodera glycines, showing increased J2 mortality and decreased egg hatching and reproductive rates (Wu et al. 2019). Fosthiazate treatment resulted in significantly smaller populations of $G$. pallida and $G$. rostochiensis juveniles at 49 and 63 days after planting, respectively, and significantly higher yields than those obtained from the untreated controls (Tobin et al. 2008). Cui et al. (2017c) demonstrated that Imi strongly increased wheat production, with 48 and 54\% reductions in soil cyst populations of $H$. avenae and $H$. filipjevi, respectively. Biological pesticides have been considered to replace chemical pesticides for the control of CCNs but the field stability and efficacies of biological pesticides need improvement (Zhang et al. 2017). Developing effective and simple chemical agents is the main strategy for CCN control. We found that Aba + Imi and MTT were very efficient against $H$. avenae and $H$. filipjevi cysts and, with these treatments, the wheat yield increased significantly.

CCNs can cause significant yield losses in semiarid and temperate regions, particularly under monoculture systems (Rivoal and Cook 1993). The success and usefulness of resistance to CCNs depend on the effectiveness and durability of the sources of resistance (Marshall and Smiley 2016; Toumi 2017). China is the world's largest producer of wheat, with a production value greater than $1.31 \times 10^{8}$ tons and an average yield of more than $54,166 \mathrm{hg} / \mathrm{ha}$ in 2018 (http://www.fao.org/faostat/en/\#data/QC), and the main wheatproducing areas are almost all irrigated fields. The economic importance of $H$. filipjevi and $H$. avenae for winter wheat under rain-fed conditions is reflected by the 42 and 50\% reductions, respectively, in wheat yields in heavily infested irrigated fields (Nicol et al. 2006; Smiley et al. 1994). CCNs are easily transferred to noninfested areas by many avenues, resulting in increased species and pathotype complexity. Although coating wheat seed with chemicals and planting combinations of $\mathrm{S}$ and $\mathrm{R}$ plants can effectively control nematode populations, damage is likely when nematodes are numerous (Cook and Starr 2006).

In conclusion, we provide the first classification of the pathotype of the $H$. avenae population from the main wheat-producing regionthe North China Plain. Our results also confirm that the $H$. filipjevi population from China corresponds to a new pathotype. Thus, we systematically demonstrated the potential benefits of developing and deploying cultivars with resistance plus seed-coating chemicals to control CCNs in the North China Plain. 


\section{Acknowledgments}

We thank the CIMMYT (Mexico) and F. Chen (Henan Agricultural University) for providing the materials; and R. W. Smiley (Oregon State University, United States), who did much work on providing scientific advice on the experiments and revising the manuscript.

\section{Literature Cited}

Andersen, S. 1959. Resistance of barley to various populations of the cereal root eelworm (Heterodera major). Nematologica 4:91-98.

Andersen, S., and Andersen, K. 1982. Suggestions for determination and terminology of pathotypes and genes for resistance in cyst-forming nematodes, especially Heterodera avenae. EPPO Bull. 12:379-386.

Chen, P. S., Peng, D. L., and Wang, M. Z. 1992. Cereal cyst nematode disease of wheat. Plant Prot. 18:37-38.

Chen, S. K., Yan, L. H., Liu, Y. L., Han, H., Sun, J. M., Bai, Q. J., and Cao, L. X. 2008. Control efficacy evaluation of $35.6 \%$ abamectin + carbendazim + thiram (FS) on soybean pests and diseases in seedling stage. Plant Doct. 21:38-40.

Cook, R., and Rivoal, R. 1998. Genetics of resistance and parasitism. Pages 322-352 in: The Cyst Nematodes. S. B. Sharma, ed. Chapman and Hall, London, U.K.

Cook, R., and Starr, J. L. 2006. Resistant cultivars. Pages 370-391 in: Plant Nematology. R. N. Perry and M. Moens, eds. CAB International, Wallingford, U.K.

Cui, J., Peng, H., Huang, W., Liu, S., Wu, D., Kong, L., He, W., and Peng, D. 2017a. Phenotype and cellular response of wheat lines carrying Cre genes to Heterodera avenae pathotype Ha91. Plant Dis. 101:1885-1894.

Cui, J. K., Huang, W., Peng, H., Kong, L. A., Li, H. X., and Peng, D. L. 2017b. Efficacy evaluation of methylene (bis) thiocyanate in combination with triticonazole and imidacloprid on controlling Heterodera avenae. J. Huazhong Agric. Univ. 36:1-5.

Cui, J.-K., Huang, W.-K., Peng, H., Liu, S.-M., Wang, G.-F., Kong, L.-A., and Peng, D.-L. 2015. A new pathotype characterization of Daxing and Huangyuan populations of cereal cyst nematode (Heterodera avenae) in China. J. Integr. Agric. 14:724-731.

Cui, J.-K., Huang, W.-K., Peng, H., Lv, Y., Kong, L.-A., Li, H.-X., Luo, S.-L., Wang, Y., and Peng, D.-L. 2017c. Efficacy evaluation of seed-coating compounds against cereal cyst nematodes and root lesion nematodes on wheat. Plant Dis. 101:428-433.

Dababat, A. A., Erginbas-Orakci, G., Toktay, H., Imren, M., Akin, B., Braun, H. J., Dreisigacker, S., Elekcioglu, I. H., and Morgounov, A. 2014. Resistance of winter wheat to Heterodera filipjevi in Turkey. Turk. J. Agric. For. 38: 180-186.

Dababat, A. A., Imren, M., Erginbas-Orakci, G., Ashrafi, S., Yavuzaslanoglu, E., Toktay, H., Pariyar, S. R., Elekcioglu, I. H., Morgounov, A. I., and Mekete, T. 2015. The importance and management strategies of cereal cyst nematodes, Heterodera spp., in Turkey. Euphytica 202:173-188.

Gao, X., Cui, L., Li, H. L., Wang, X. M., Tang, W. H., Robert, L. C., Lin, X. H., and Li, H. J. 2012. Resistance of Triticum durum cultivars Waskana and Waskowa to cereal cyst nematode, Heterodera filipjevi and H. avenae. Acta Agron. Sin. 38:571-577.

Hao, R., Huang, W. K., Liu, C., Peng, D. L., Li, H. M., and Li, H. X. 2014. Effect of seed-coatings on controlling cereal cyst nematode (Heterodera avenae) of wheat. Plant Prot. 40:182-186.

Holgado, R., Andersson, S., Rowe, J. A., and Magnusson, C. 2004. First record of Heterodera filipjevi in Norway. Nematol. Mediterr. 32:205-211.

Hou, S. Y., Ma, L., Li, C. G., Xie, C. H., Hou, L., Zhang, G., and Peng, D. L. 2018. Resistance evaluation of 209 foreign spring wheat germplasm to Heterodera avenae. J. Triticeae Crops. 38:35-40.

Hou, S. Y., Wang, A. L., Zhang, G., and Huang, L. L. 2012. Effect of cereal cyst nematode on agronomic characteristics and yield losses of spring wheat. J. Agric. 2:31-36.

Ireholm, A. 1994. Characterization of pathotypes of cereal cyst nematodes, Heterodera spp., in Sweden. Nematologica 40:399-411.

Jagdale, G. B., and Grewal, P. S. 2002. Identification of alternatives for the management of foliar nematodes in floriculture. Pest Manage. Sci. 58:451-458.

Large, E. C. 1954. Growth stages in cereals illustration of the Feekes scale. Plant Pathol. 3:128-129.

Li, X. H., Juan, M. A., Gao, B., Wang, R. Y., and Chen, S. L. 2013. Resistance of wheat cultivars or germplasm lines to Heterodera avenae. J. Triticeae Crops. 33:1277-1283.

Liu, B. L., Sun, C. G., Wang, X., Xiang, G. L., Song, Z. Q., Gao, F. F., and Li, H. M. 2012. Evaluation of the resistance of wheat cultivars to Peixian population of Heterodera avenae from Jiangsu Province, China. J. Triticeae Crops. 32:563-568.

Liu, J., Wu, H. Y., and Peng, D. L. 2012. Evaluation of the main wheat varieties from Shandong for resistance to Heterodera avenae. Crops. $1: 111-114$.

Marshall, J. M., and Smiley, R. W. 2016. Spring barley resistance and tolerance to the cereal cyst nematode Heterodera avenae. Plant Dis. 100:396-407.

Murray, G. M., and Brennan, J. P. 2009. Estimating disease losses to the Australian wheat industry. Australas. Plant Pathol. 38:558-570.
Nicol, J., Ogbonnaya, F., Singh, A., Bishnoi, S., Kanwar, R., Li, H. L., Chen, S. L. Peng, D. L., Bolat, N., and Sahin, E. 2009. Current global knowledge of the usability of cereal cyst nematode resistant bread wheat germplasm through international germplasm exchange and evaluation. Pages 149-153 in: Cereal Cyst Nematodes: Status, Research and Outlook. I. T. Riley, J. M. Nicol, and A. A. Dababat, eds. CIMMYT, Ankara, Turkey.

Nicol, J. M., Bolat, N., Sahin, E., Tulek, A., Yildirım, A. F., Yorgancilar, A., Kaplan, A., and Braun, H. J. 2006. The cereal cyst nematode is causing economic damage on rain-fed wheat production systems of Turkey. (Abstr.) Phytopathology 96:S169.

Nicol, J. M., Turner, S. J., Coyne, D. L., den Nijs, L., Hockland, S., and Maafi, Z. T. 2011. Current nematode threats to world agriculture. Pages 21-43 in: Genomics and Molecular Genetics of Plant-Nematode Interactions. J. T. Jones, G. Gheysen, and C. Fenoll, eds. Springer Verlag, Dordrecht, The Netherlands.

Ogbonnaya, F. C., Seah, S., Delibes, A., Jahier, J., Lopez-Brana, I., Eastwood, R. F., and Lagudah, E. S. 2001. Molecular-genetic characterisation of a new nematode resistance gene in wheat. Theor. Appl. Genet. 102: 623-629.

Peng, D. L., and Cook, R. 1996. Observation on pathotypes of cereal cyst nematode (Heterodera avenae) in China. Int. J. Nematol. 6:176-178.

Peng, D. L., Nicol, J. M., Li, H. M., Hou, S. Y., Li, H. X., Chen, S. L., Ma, P., Li, H. L., and Riley, I. T. 2009. Current knowledge of cereal cyst nematode (Heterodera avenae) on wheat in China. Pages 29-34 in: Cereal Cyst Nematodes: Status, Research and Outlook. I. T. Riley, J. M. Nicol, and A. A. Dababat, eds. CIMMYT, Ankara, Turkey.

Peng, D. L., Ye, W. X., Peng, H., and Gu, X. C. 2010. First report of the cyst nematode (Heterodera filipjevi) on wheat in Henan Province, China. Plan Dis. $94: 1262$.

Peng, H., Li, X., Cui, J. K., Peng, D. L., Huang, W. K., He, W. T., and Kong, L. A. 2016. First report of cereal cyst nematode, Heterodera filipjevi, on wheat from Anhui Province, China. Plant Dis. 100:536.

Peng, H., Qi, X., Peng, D., Long, H., He, X., Huang, W., and He, W. 2013. Sensitive and direct detection of Heterodera filipjevi in soil and wheat roots by species-specific SCAR-PCR assays. Plant Dis. 97:1288-1294.

Peng, H., Zhang, Y. D., Cui, J. K., Li, X., Huang, W. K., Kong, L. A., He, W. T., and Peng, D. L. 2018. First report of cereal cyst nematode (Heterodera filipjevi) on winter wheat in Xinjiang Uygur Autonomous region, China. Plant Dis. 102 454

Persmark, L., Banck, A., Andersson, S., and Jansson, H.-B. 1992. Evaluation of methods for extraction of nematodes and endoparasitic fungi from soil. Nematologica 38:520-530.

Pullen, M. P., and Fortnum, B. A. 1999. Fosthiazate controls Meloidogyne arenaria and $M$. incognita in flue-cured tobacco. J. Nematol. 31:694-699.

Qi, X. L., Peng, D. L., Peng, H., Long, H. B., Huang, W. K., and He, W. T. 2012. Rapid molecular diagnosis based on SCAR marker system for cereal cyst nematode. Sci. Agric. Sin. 45:4388-4395.

Rivoal, R., Bekal, S., Valette, S., Gauthier, J. P., Fradj, M. B. H., Mokabli, A., and Yahyaoui, A. 2001. Variation in reproductive capacity and virulence on different genotypes and resistance genes of Triticeae, in the cereal cyst nematode species complex. Nematology 3:581-592.

Rivoal, R., and Cook, R. 1993. Nematode pests of cereals. Pages 259-303 in: Plant Parasitic Nematodes in Temperate Agriculture. K. Evans, D. L. Trudgill, and J. M. Webster, eds. CAB International, Wallingford, U.K.

Singh, R. P., Hodson, D. P., Huerta-Espino, J., Jin, Y., Bhavani, S., Njau, P., Herrera-Foessel, S., Singh, P. K., Singh, S., and Govindan, V. 2011. The emergence of Ug99 races of the stem rust fungus is a threat to world wheat production. Annu. Rev. Phytopathol. 49:465-481.

Smiley, R. 2014. Resistance of wheat to a Pacific Northwest population of Heterodera avenae. Plant Dis. Manage. Rep. 8:CF039. https://www.plantmanagementnetwork. org/pub/trial/PDMR/volume8/abstracts/CF039.asp

Smiley, R. W. 2009. Occurrence, distribution and control of Heterodera avenae and $H$. filipjevi in the western USA. Pages 35-40 in: Cereal Cyst Nematodes: Status, Research and Outlook. I. T. Riley, J. M. Nicol, and A. A. Dababat, eds. CIMMYT, Ankara, Turkey.

Smiley, R. W., Dababat, A. A., Iqbal, S., Jones, M. G. K., Tanha Maafi, Z., Peng, D., Subbotin, S. A., and Waeyenberge, L. 2017. Cereal cyst nematode: A complex and destructive group of Heterodera species. Plant Dis. 101: $1692-1720$

Smiley, R. W., Gourlie, J. A., Rhinhart, K. E. L., Marshall, J. M., Anderson, M. D., and Yan, G. 2012. Influence of nematicides and fungicides on spring wheat in fields infested with soil borne pathogens. Plant Dis. 96:1537-1547.

Smiley, R. W., Ingham, R. E., Uddin, W., and Cook, G. H. 1994. Crop sequences for managing cereal cyst nematode and fungal populations of winter wheat. Plant Dis. 78:1142-1149.

Smiley, R. W., Yan, G., and Pinkerton, J. N. 2011. Resistance of wheat, barley and oat to Heterodera avenae in the Pacific Northwest, USA. Nematology 13: 539-552.

Subbotin, S. A., Manuel, M. O., and Baldwin, J. G. 2010. Nematology monographs and perspectives 8B. Pages 181-187 in: Systematics of Cyst Nematodes (Nematode: Heteroderinae). D. J. Hunt and R. N. Perry, eds. Brill, Leiden, The Netherlands. 
Tobin, J. D., Haydock, P. P. J., Hare, M. C., Woods, S. R., and Crump, D. H. 2008. Effect of the fungus Pochonia chlamydosporia and fosthiazate on the multiplication rate of potato cyst nematodes (Globodera pallida and G. rostochiensis) in potato crops grown under UK field conditions. Biol. Control 46:194-201.

Toktay, H., Imren, M., Bozbuga, R., Erginbas Orakci, G., Dababat, A. A., and Elekcioglu, I. H. 2013. Pathotype characterization of the cereal cyst nematode Heterodera filipjevi (Madzhidov, 1981) Stelter in Turkey. Turk. Entomol. Derg. 37:213-219.

Toumi, F. 2017. Cereal cyst nematodes: Molecular identification and quantification, and screening for resistance in wheat. Doctoral dissertation, Ph.D. thesis, Ghent University, Ghent, Belgium.

Woods, S. R., Haydock, P. P. J., and Edmunds, C. 1999. Mode of action of fosthiazate used for the control of the potato cyst nematode Globodera pallida. Ann. Appl. Biol. 135:409-415.

Wu, H. Y., Luo, M., Zhang, L. Y., and Zhou, X. B. 2019. Nematicidal activity of fosthiazate against soybean cyst nematode Heterodera glycines. J. Nematol. 51: $1-9$.

Xing, X., Yuan, H., Sun, J., Zhang, J., Sun, B., and Li, H. 2014. Resistance to two species of cereal cyst nematode and evaluation methods in major wheat cultivars from Henan Province, China. Acta Agron. Sin. 40:805-815.

Yuan, H., Nian, G., Xing, X., Fu, B., Zhang, P., and Li, H. 2011a. Identification of pathotypes of four populations of cereal cyst nematode in the border on Shandong, Henan and Anhui provinces. Acta Phytophylac. Sin. 38:408-412.
Yuan, H.-X., Sun, J.-W., Yang, W.-X., Xing, X.-P., Wang, Z.-Y., Riley, I. T., and Li, H.-L. 2010. New pathotypes of Heterodera avenae (cereal cyst nematode) from winter wheat in Zhengzhou, Henan, China. Australas. Plant Pathol. 39: 107-111.

Yuan, H.-X., Zhang, F.-X., Zhang, J.-J., Hou, X.-S., Li, H.-J., and Li, H.-L. 2011 b. Resistance of CIMMYT wheat germplasm to Heterodera filipjevi Xuchang population from Henan Province, China. Acta Agron. Sin. 37:1956-1966.

Zhang, D., Wang, H., Ji, X., Wang, K., Wang, D., and Qiao, K. 2017. Effect of abamectin on the cereal cyst nematode (CCN, Heterodera avenae) and wheat yield. Plant Dis. 101:973-976.

Zhao, H. H., Yang, Y. Y., and Peng, D. L. 2012. Preliminary evaluation on resistance of main wheat cultivars from Shandong province to cereal cyst nematode. Shandong Agric Sci. 44:80-83.

Zhen, H. Y., Peng, H., Zhao, H. H., Qi, Y. Y., Huang, W. K., Kong, L. A., Liang, C., Wen, Y. H., and Peng, D. L. 2018. First report of cereal cyst nematode (Heterodera filipjevi) on winter wheat in Shandong Province, China. J. Integr. Agric. 17:1912-1913.

Zheng, J. W., Cheng, H. R., and Fang, Z. D. 1995. Comprehensive assessment of three extraction methods of cysts of Heterodera species from soils. Plant Prot. 21:50-51.

Zheng, J. W., Cheng, H. R., and Fang, Z. D. 1997. Pathotype of cereal cyst nematodes (Heterodera avenae) on wheat in Shanxi and Anhui, China. Acta Phytopathol. Sin. 27:309-314.

Zheng, J. W., Lin, M. S., Cheng, H. R., and Fang, Z. D. 1999. Resistance of cereal cultivars to cereal cyst nematode, Heterodera avenae. J. Plant Prot. 26:250-254 